\title{
Organizational, Ecological and Economic Aspects of Regional Hunting Tourism Development in Russian Federation
}

\author{
${ }^{1}$ Valery S. Misakov, ${ }^{2}$ Aksana B. Zherukova, ${ }^{3}$ Anna Yu. Adzhieva, ${ }^{4}$ Leila B. Baysultanova, ${ }^{5}$ Muslim I. \\ Chazhaev \\ ${ }^{1}$ Doctor of Economics, Senior Researcher of the Tembotov Institute of Ecology of Mountain Territories of Russian \\ Academy of Sciences \\ ${ }^{2}$ Doctor of Economics, Associate Professor of the Department of Economics and Management in Tourism at \\ FSBEI HE "Kabardino-Balkarian State University named after H.M. Berbekov \\ ${ }^{3} \mathrm{Ph} . \mathrm{D}$. in Economics, Associate Professor of the Department of Money Circulation and Credit, FSBEI HE "Kuban \\ State Agrarian University" \\ ${ }^{4} \mathrm{Ph}$.D. in Economics, Associate Professor of the Department of Economics and Management in Tourism at FSBEI \\ HE "Kabardino-Balkarian State University named after H.M. Berbekov \\ ${ }^{5} \mathrm{Ph} . \mathrm{D}$. in Economics, Associate Professor of the Department "Management and State and Municipal \\ Administration" of FSBEI HE "Chechen State University" \\ Email:mbc_@mail.ru
}

Received: $11^{\text {th }}$ January 2019, Accepted: $25^{\text {th }}$ January 2019, Published: $28^{\text {th }}$ February 2019

\begin{abstract}
With the transition to market relations, hunting tourism became an independent direction of work for hunting organizations of Russian Federation, and for most farms it became almost the only source of livelihood. The development of hunting tourism in the face of fierce competition is associated with the need to address legal, social, organizational, economic and environmental issues.
\end{abstract}

Keywords

Market Economy, Hunting Tourism, Foreign Experience, Competition, Population of Hunting Animals, Sustainable Development, Management

\section{Introduction}

The development of market relations in Russian Federation could not help but have a negative effect on the economic and legal relations of any economic object, including the hunting farms. The "ideology" of the hunting system was destroyed, and not only in the economic aspect. In market economy conditions, all hunting enterprises, regardless of the form of ownership, are forced to seek new sources of funding for staff, material and technical base, and natural resource maintenance and development. A significant source of this process can and should be hunting tourism - one of the types of regional tourism [7]. This type of tourist activity is carried out on the basis of hunting farms with the hunting for animals. According to experts, export-oriented hunting tourism can bring the annual income for Russian Federation in the amount of 15 million US dollars [14].

Although private hunting areas appeared in the regions, along with the state ones, the key provisions for the use of hunting areas, hunting animals and even certain types of weapons need to be regulated strictly. There were also quite a few property owners who use this legislation gap "skillfully", without worrying about the reproduction of natural resources.

\section{Study Methods}

The object of the study is the problems and organizational, environmental and economic aspects of regional hunting tourism formation and development in Russian Federation. They used various methods of economic research: logical and comparative analysis, functional and system approach, polyfactorial monitoring, observation

\section{Study Results}

An exceptional feature of hunting tourism is that it carries both elements of the hunting economy and the elements of tourist business. This means that the regulation of its activities falls under both the Law on Hunting, Fauna and under the Law on Tourist Activities. In other words, hunting tourism is carried out at the junction of 2 directions, thus it is subject to mandatory settlement by state hunting management structures and the state management structures for tourist activities.

It is well known that without special knowledge and legal permission of social, legal, organizational, economic and environmental objectives it is impossible to achieve high results in this business. Today it is necessary not just to go hunting, but to organize and conduct hunting tours reliably and attractively so that they bring psychological satisfaction and economic benefits to all participants of that process. It should be noted that no hunting farm of the Kabardino-Balkarian Republic revealed the presence of staff with a special tourist education.

In the course of the study, we interviewed 12 tourist hunters who came from Germany, Austria, etc. - what are the main problems in the organization of this type of business in the republic according to their opinion? 
Almost all of them said that it is quite difficult to resolve the issues related to the conclusion of contracts in Russian Federation quickly, there are a lot of ambiguities in rules and documents. In particular, they have an absolutely serious misunderstanding, concerning the questions of officials, in their opinion, unrelated to the hunt. For example, the date and place of their birth, etc. By the way, foreign hunting companies, which send their clients to Russia, also do not want to report this. At the same time, none of them (to our surprise) spoke negatively on living conditions.

Russia recognized the world CITES system, which regulates the rules of hunter entry, residence, and the export of a hunting trophy from the country, etc. If it is issued within 2-3 days in Germany, then this period may take up to 45 days in Russia. This situation is suspicious among foreign hunters who stand for the "purity" of hunting organization.

And this despite the fact that there is a real struggle for every hunter, especially foreigners, and hunting farms, like any other market economy subjects, function in tough competition terms. Over the past two decades, the number of foreign hunters arriving in Russia with the goal of participating in hunting tourism has increased multiply and made more than 2,000 people. Moreover, this increase will be increased seriously, because, for example, in the countries of Western Europe, on the one hand, the areas of hunting grounds are very insufficient, and on the other hand, there are very high prices for hunting there. For example, it is more profitable for an Austrian to fly to Russia to hunt for wood grouse and black grouse than to buy a license for wood grouse at home [12]. The cost of tour organization for foreigners in the CBR ranges from 2.5 to 10 thousand US dollars (according to the principle of agreement). Under these conditions, we believe that it is advisable to settle certain provisions of the Federal Law "On Hunting and Hunting Farm" by the Decree of RF Government, in particular, concerning the form of THE agreement on animal extraction, the form of the agreement on damages .

However, the market for hunting services is highly competitive. Success depends on many factors - the cost of tour, punctuality of accommodation, quality of food, the cleanliness of living conditions, the availability of an interpreter, the level of service, the quality of transport service, the staff friendliness and professionalism .

The host should always remember that the guests came to them to rest, for the pleasure, hoping for quality service for their money.

For a science-based organization of hunting tourism, it is necessary to solve the complex of socio-ecologicaleconomic and legal problems, because without their rational solution it is impossible to carry out an effective use of hunting resources. At the same time, it is necessary to create the conditions under which the participation in hunting tours would be mutually beneficial to all participants, both the inviting party and guests. For example, one can argue about the appropriateness of such a situation when a specially protected area receives the right to conduct hunting tours in buffer and specially designated operational areas adjacent to them to solve financial problems. These are, for example, the Sayano-Shushensky Biosphere Reserve, the "Vugyd-Va" National Park (Komi Republic), etc. At the same time, one cannot go to extremes for the sake of financial well-being. We believe that the hunting in specially protected areas is unacceptable to solve the problems of national park research financing. In this case, in our opinion, the experience of a number of African countries is very attractive, where hunting is skillfully and scientifically-organized in national parks and reserves, moreover, it has become a significant sector of the economy [6].

The practice of regulated hunting tourism conduct in these countries has long and convincingly proved that such hunting helps to improve the quality of populations seriously, moreover, to protect rare species of animals, to increase the hunting culture, not to mention the ecological component. Moreover, properly organized legal hunting is one of the levers of poacher extrusion.

(In our case, we omit the topic of illegal, unregulated hunting tourism as a subject of a separate study. It is noteworthy - according to the B. Zhitkov All-Russian Research Institute of Hunting and Animal Farming, no more than 9 illegal animal-hunting offenses are revealed out of 1,000 ones in Russian Federation).

In the course of working on this problem, we studied the experience of the post-Soviet republics concerning the organization of hunting for foreigners.

In Belarus, Ukraine, Tajikistan and other CIS countries state forestries dominate (for example, Belgosohota). All hunting farms get shooting limits, but they have the right to find partners independently.

In the Baltic countries - Latvia, Lithuania, Estonia - almost all hunting farms are privately owned (Felis, Hubertis Baltic Lid and others), the state does not participate in this type of activity and is limited only to the establishment of hunting periods.

We would especially like to draw the attention to the experience of hunting farm development in Portugal. In the northern territories of the country, "democracy" was introduced in the hunting business, in other words, there was no state control over the organization of hunting for animals, which soon brought to nothing all the hunting activity due to the extermination of animals. At the same time, in the southern regions of the country, a tight control was exercised over private and collective hunting farms. Thus, it was possible to preserve the population of animals, among other things.

The supporters of "democratic" hunting were forced to admit their mistakes. Unfortunately, the Portuguese lessons were not taken into account in the development of our hunting industry.

The experience of hunting organization in the United States is interesting. It is noteworthy that, for example, hunting is not licensed in the state of Alaska - a hunter can shoot any number of animals, moreover, any kind of 
them. The only regulator is the hunt timing (period). In California, even the registration of an outfitter (a hunting services firm) is not required.

The object of our research are the hunting farms and the lands of the Kabardino-Balkarian Republic.

The total area of the CBD hunting grounds makes 1048.9 thousand hectares. There is one state reserve and one national park in the republic with the total area of more than 180.0 thousand hectares and eight natural reserves (about 150.0 thousand hectares), for which hunting is prohibited. 66\% of the hunting grounds belong to the state, the rest - to private and legal entities. The objects of hunting in the republic are 8 species of birds and more than 20 species of mammals. The main types of wild animal use are amateur and sport hunting [4].

There are 7 hunting users in the republic: the Federal State Institution "Nalchik State Experimental Hunting Industry" and 6 hunting farms with which, according to the results of the auctions in 2012, the hunting agreements were concluded: OVOH Geduko LLC, OVOH Kharakhora LLC, Urochishche Ekiptsoko LLC ", Petrovs Collective Farm, Ushtulu LLC and OFH In-Tour LLC.

The main activities of the hunting farms of the republic are the following ones:

- Keeping of records on the number and the organization of hunting resource monitoring;

- Implementation of planned hunting and biotechnical activities;

- Production hunting control;

- Keeping and the breeding of hunting animals in semi-free conditions and in artificially created habitat;

- Taking measures to protect hunting resources from diseases;

- Implementation of preventive and fire-prevention works in order to protect forests from fires;

- Regulation of the number of predatory animals in order to maintain the number of hunting resources, to prevent the occurrence and the spread of diseases from hunting resources, to prevent the damage to the health of citizens, wildlife objects and their environment;

- Amateur and sport hunting $[2,3,4]$.

Through the prism of foreign experience in the organization of hunting tourism, we tried to analyze the way the hunting tourism is organized in the Kabardino-Balkarian Republic; what is the state of the main populations of hunting animals; how marketing activities are organized in the field of hunting tourism, etc., in order to develop practical recommendations for hunting farm activity improvement.

In order to determine the effectiveness of the hunting economy at least the following indicators are needed:

- Area of assigned hunting grounds;

- Total costs of hunting;

- Total costs of 1000 hectares of land;

- Income from hunting activities;

- Income from activities on 1000 hectares of land;

- Income per 1 ruble of investments;

- Expenses for the protection and the reproduction of wild animals;

- Expenses for the security on 1000 hectares of land.

To our great misunderstanding and disappointment, the heads of hunting farms, referring to the right of commercial secret, refused to provide us with the required financial and economic indicators of their farm activities requested for research. Such an example is typical and pertinent - with the arrival of a new manager at NGOOH in 2017, the farm "showed" 6 million rubles of revenues in the report, although the revenues did not exceed 1.5 million rubles during previous years in the same conditions, with the same staff, etc.

The direct state regulator of hunting tourism in the republic is the Department of Protection, Federal Supervision, and Regulation of Fauna and their Habitat Use. This department deals with hunting and trapping of wild animals, including the provision of services in these areas, and gives hunting organizations a number of licenses within the allocated limits [10].

On average, about 25 foreign hunters visit the Republic annually, more than $80 \%$ of which come to get large animals (Caucasian goats, wild boars, bears). And, unlike the local hunters, they are not interested in the meat of animals at all. For them the high-quality, desired trophies are horns, canines and skins. Such an approach forces local hunting farms to adapt to these circumstances, to withstand hunting periods.

However, apparently due to the lack of hunting culture, there is no particular desire to form the necessary sex and age structure of the population in local hunting farms, which would allow to get (grow) the necessary number of males with particularly attractive trophy properties. The process of shooting animals is necessary not only to control - it is necessary to manage it, which will allow to take into account the ratio of age groups of males from this population $[1,8,9]$.

In the course of research and the communication with many hunt managers and rangers of the republic, we were convinced that every hunter tries to shoot only the largest Caucasian goat. It should be noted that no one in the republic studies the impact of such (trophy) hunting on the state of Caucasian goat population - the pride of the animal world in Caucasus. There is no statistics about the average mass of horns of the shot Caucasian goats in 
dynamics, even in the form of expert statements. Under these conditions, it seems necessary to involve the IEGT (named after A.K. Tembotov) scientists in this process systematically.

Moreover, considering the significance of this problem, the Government of the CBR, in our opinion, needs to find financial resources in 2019 to conduct special events and develop the mechanism for humane organization of trophy hunting.

We must also stipulate that we are not the supporters of a boundless increase of animals, including Caucasian goats, because this is not only unjustified, but even harmful to the population.

A similar situation has developed for bears. The scientists in the field of hunting point out that hunters, poachers shoot them without regard - whether these are old animals or young ones. In the areas of the Western Caucasus A.I. Kudatkin [11] conducted the in-depth studies to determine the effect of 70-year trophy hunting on the state of bear population number and quality. The researcher revealed that there were less of these species, which resulted in a catastrophic reduction of large bears (identified in the Caucasian reserves) from 83\% in 1928-1939 up to 3.7\% in 2000. And all this despite the fact that the hunt was officially banned here! All this suggests the need to develop the republican standards to establish the optimal parameters of animal density per $100 \mathrm{~km} 2$, naturally, taking into account seasonal migrations.

The development of export-oriented hunting tourism in the republic is still weak. It is necessary to develop the standards for the organization of hunting activities that meet international requirements in this area. This will make it possible not only to increase the investment attractiveness of the industry, but also to strengthen its economic position and secure qualified personnel significantly.

There are no intermediary hunting firms in the republic. However, such hunting companies are able to implement many important functions effectively, including:

- Establishment of business contacts with similar foreign hunting firms for client exchange;

- Advertising of local (regional) hunting areas for certain types of animals, the development of exhibition booklets;

- Drawing up of visas, the obtaining of permits necessary for hunting, the obtaining of CITES documents, international veterinary certificate, the passing of border and customs control;

- Planning of tours, flight ticket purchasing within the country.

$\mathrm{OOH}$ state regulatory agencies do not bear any legal and economic responsibility for the unprofitable economic consequences of their decisions, since, in accordance with the law, they cannot carry out economic activities. Moreover, the state is not engaged in procurement (a kind of "state order"), but also refused to stimulate the production of hunting products. All this affects the earnings of industry workers, contributes to the growth of the shadow economy, etc., which, in our opinion, requires the increase of state hunting management structure legal and economic responsibility.

Hunting tourism in the republic is organized in accordance with RF Constitution, the relevant federal laws "On the Animal World", "On Environmental Protection" and others.

The algorithm of wild animal accounting organization and conduct is the following one in the republic.

Every February the animals were counted by the staff of CBR MLH in the Republic districts (For some reason, animals are registered at other times in nature reserves and the CBR National Park). As a rule, it is carried out by a run accounting method and winter route accounting (by the number of animal tracks in snow) [13].

During the first method of accounting, the animals are run with a pre-selected typical record platform, and the animals are counted visually. Traditionally, it is assumed that the survey of about $10 \%$ of the hunting farm territory provides sufficient information in this way.

Based on the processing and the summarizing of the obtained data on the number of animals, the CBR Ministry of Forestry makes an application for hunting resource extraction limit to RF Ministry of Natural Resources and Ecology. After these procedures, the republic receives an agreed limit on the extraction of hunting resources for the next hunting season.

It should be noted that everything happens in public - these limits are subject to environmental and public expertise, the projects of limits are advertised in the "Kabardino-Balkarskaya Pravda" newspaper.

After the completion of all necessary procedures, the agreed limit on the extraction of hunting resources is approved by the decree of the Head of the Republic and CBR MLH is brought to the hunting farms. Table 1 shows the catch limit of the Caucasian goat during the hunting season of 2018-2019, approved by order of the Kabardino-Balkarian Republic Head N 73-WP issued on July 20, 2018.

\begin{tabular}{|l|l|l|}
\hline Item No & Hunting Farm Name & $\begin{array}{l}\text { Caucasian Goat (1 Year and } \\
\text { older) (No. of Species) }\end{array}$ \\
\hline 1. & FSBI "NGOOH" Hunting Area N 1 (Zolsky District) & 8 \\
\hline 2. & FSBI "NGOOH" Hunting Area N 4 (Elbrus, Chegem Districts) & 86 \\
\hline 3. & FSBI "NGOOH" Hunting Area N 5 (Chereksky District) & 10 \\
\hline 4. & FSBI "NGOOH" Hunting Area N 6 (Leskensky, Urvansky, & 16 \\
\hline
\end{tabular}




\begin{tabular}{|l|l|l|}
\hline & Chereksky Districts) & \\
\hline 5. & Public Hunting Areas of Elbrus Region & 4 \\
\hline 6. & Public Hunting Areas of Chegemsky Area & 3 \\
\hline 7. & Open-air Hunting grounds of Chereksk District & 4 \\
\hline 8. & The Hunting Area "In-Tour" of Chereksk District & 15 \\
\hline 9. & The Hunting Site "Ushtulu" of Chereksk District & 7 \\
\hline \multicolumn{2}{|l|}{ Total Amount of Hunted Animals: } & 153 \\
\hline
\end{tabular}

Table 1: The Limit of Hunting Resources in the Kabardino-Balkarian Republic for the Period from August 1, 2018 to August 1, 2019

\section{(Except for Hunting Resources Located on Specially Protected Natural Areas of Federal Significance)}

The method of accounting for hunting animals developed by the Federal State Institution "Control Information and Analytical Center for Hunting Animals and Their Habitat" and recommended by the Department of Hunting Facilities of RF Ministry of Agriculture are used to account for by the run method.

In our opinion, it is incorrect to apply them in our high mountain conditions, since they were developed for lowland territories.

Moreover, there are technical developments that allow to conduct a complete account of animals. For example, IEGT named after A.Tambotov has two drones: "DJI Mavic Pro Platinum" and "DJI Phantom 4 Pro", which can be used by the Department of CBR MLB.

Another problem is the lack of fundamentals and ecological tourism in the Republic, although the region has all the conditions for its proper development. It seems to us that the initiators of this movement should be environmentalists and biologists, coupled with travel companies. It is obvious that lawyers, managers, economists will immediately catch up to them. It opens a whole niche, a virgin land - it will be necessary to develop a set of pricing policy, marketing, information and advertising support issues. It is enough to note that there is still no legally approved concept of ecotourism status in Russian Federation. In other words, it means the absence of any form of state support.

An exceptional value of ecotourism is the focus of its participants on the preservation of biological diversity and ethno-cultural characteristics of the territory. Ecotourism excludes any interference in the natural landscape, any negative impact on it. Moreover, nowadays ecotourism gives society a unique opportunity to maintain the necessary balance of environmental social and economic interests. In many countries, ecotourism becomes an effective sector of the economy, which preserves the biological diversity and cultural characteristics of the territory, and also allows you to create tens of thousands of new jobs. For example, in the US, over one million of new jobs have been created due to ecotourism. In Canada, the tax revenues from ecotourism activities exceeded $\$$ 2.0 billion. Experts note that ecotourism can be the top priority for world tourism development. Today, the needs of ecotourism in the world produce the goods and services in the amount of up to 70 billion US dollars annually.

Another positive effect of ecotourism development is the nature protection, environmental education and the growth of local population culture carried out under these conditions. At that it should be clearly stated that no form of outdoor recreation can be considered as ecotourism if it is not intended to preserve the environment.

During the conversations with some leaders of hunting grounds, we were interested in the reasons that restrain the development of ecotourism in the republic. We have to admit an absolute lack of the problem understanding, the prevalence of the prevailing stereotypes - "survival is the top priority". The leaders of hunting farms are more focused on their personal experience, intuition, they often unwilling to improve their skills.

The republic does not train personnel that would be able to draw up and develop targeted programs for ecological tour conduct. On the other hand, our hunting grounds and even nature reserves and national parks today are not able to present anything to ecotourists, except for the same type, unchanging and sometimes lifeless landscapes, not to mention any infrastructure.

The following example is indicative. The Finnish owners of forest land, competently conducting the necessary biotechnical activities, have learned to "poach" bears from the adjacent territories of Russia! The situation reached the point that the residents of these already deserted Russian regions visit the bear reserves of "Kuhmo", "Marfincelkontn" and other ecological parks of Finland for hunting tours [5].

A constant attribute of the ecological tourist is digital photo and video equipment - the photographing of wild animals and nature is performed by tens of millions of people today. An entire caste of birdwatchers appeared.

The Republic has many corners, which can be of great interest among the consumers of ecological tours. Almost every area of the CBR has a variety of landscapes, many endemic species and subspecies of various wild animals. All this suggests that Kabardino-Balkaria can become a kind of wildlife exporter.

\section{Conclusions and Offers}

The foregoing allows us to assert that in order to develop the competitive advantages of RF regional hunting farms it is necessary to develop the following:

- The standards for the organization and the conduct of hunting tourism that meet international standards, focused on the ecological approach; 
- A special strategy for wild animal protection and use, including information and analytical support, monitoring, the system of sanctions and incentives;

- The regional standards to establish the optimal density parameters of animals per $100 \mathrm{~km}^{2}$, taking into account seasonal migrations.

- To increase the activity of advertising operations in order to popularize regional hunting and eco-tourism in environmental education of population, the positioning of the Kabardino-Balkarian Republic as an ecologically advanced territory;

- Kabardino-Balkarian State University named after H.M. Berbekov and Kabardino-Balkarian State Agrarian University named after V.M. Kokov should train the experts in the field of recreational environmental management for ecological tour conduct.

- To propose to the business community of the Republic to work out the issue of a hunting intermediary company creation, which will undoubtedly allow to promote regional hunting and eco-tourism taking into account environmental sustainability and productive longevity of natural systems.

\section{Conflict of Interest}

The authors confirm that the presented data does not contain a conflict of interest.

\section{References}

1. Federal Law N 52-FL “On the Animal World" issued on April 24, 1995.

2. The Federal Law (July 24, 2009) N 209-Ф3 “On Hunting and the Conservation of Hunting Resources, and on Amendments to Certain Legislative Acts of Russian Federation".

3. The law of the Kabardino-Balkarian Republic (November 7, 2008) N 62-RZ "On the Protection and Use of Fauna Objects".

4. The Concept of the Development of the Hunting Economy Development in the Kabardino-Balkarian Republic until 2030. Nalchik. 2016.

5. Algren S. Hunting in Finland // Hunting and Hunting Farms. 1991. №11. pp. 40-41.

6. Wagner Zdenek. African Safaris - What is it? // Safari - 2002. pp. 31-36.

7. Vashukevich Yu.E. Hunting Tourism in Russia//Organizational and Economic Aspects. Irkutsk. 2001.-147 p.

8. Weinberg P., et al. The Problem of the Conservation and the Sustainable Use of the Animal World Biodiversity. Alma-Ata. 1999.

9. Grakov N.N. The Management of Hunting Animal Populations. Kirov. 1999. - 209 p.

10. Kalazhokov Kh.Kh., Misakov V.S., Uvizheva F.Kh., Goygova M.G., Khochueva Z.M. Some Problems of Hunting Farm Design in the Region, taking into account the Requirements of Competing Population Demography // Economy and Entrepreneurship. 2018. №11.

11. Kudatkin A.N. The State of Populations and the Problems of Caucasian Bear Protection. M.: 2002. pp. 42-52

12. Melnikov V.V. Hunting Tourism Today: Problems and Solutions // Safari. 2001. №2. pp. 24-26

13. Guidelines for the Registration of Hunting Animals on the Grounds by the Method of Run. M.: The Ministry of RF Agriculture. 2018.

14. Thummler Hubert. Iran is Open and Ready for Hunting // Safari-November. 2000. p. 69 